Bull. Fac. Agric., Cairo Univ., 71:95-105(2020).

\title{
YIELD AND QUALITY RESPONSE OF SOME SUGAR BEET VARIETIES TO NITROGEN AND BORON FERTILIZATION IN SANDY SOIL
}

(Received: 22.6.2020)

\author{
By \\ E.F.A. Aly, H.M.Y. El-Bakary and "N. E. G. Mekhaile \\ Variety Maintenance Research Department. Sugar Crops Research Institute and * Central \\ Laboratory for Design \& Statistical Analysis Research, Agriculture Research Center, Giza, Egypt.
}

\begin{abstract}
Two field experiments were carried out at El-Nubaria, El-Buhira Governorate Egypt, during $2017 / 2018$ and 2018/2019 seasons. The objective was to study the effect of foliar applications ( 0 and $150 \mathrm{ppm} /$ fed of boron) and nitrogen fertilization levels (80,100 and $120 \mathrm{~kg} \mathrm{~N} / \mathrm{fed}$ ) on response, yield and quality of three sugar beet varieties (Betamax, Dena and Sara) in sandy soil. A split-split plot design with three replicates was used. The seeds of the three varieties were sown on the $1^{\text {st }}$ week of October and harvested after 210 days in both seasons. The obtained results showed that foliar application of $150 \mathrm{ppm}$ boric acid/fed recorded a significant increase in root fresh weight and root yield values in both seasons compared to the control. While, foliar application of boron caused a positive reduction effect on impurities ( $\mathrm{Na}, \mathrm{K}$ and alpha amino-N). However, it corrected sugar \%, quality of sugar index and sugar yield. Soil application of $100 \mathrm{~kg} \mathrm{~N} /$ fed resulted in significant increases in root fresh weight, roots and tops yields $(\mathrm{t} / \mathrm{fed})$ in both seasons, compared with plots treated with $80 \mathrm{~kg} \mathrm{~N} / \mathrm{fed}$, respectively. Fertilizing sugar beet plants with $100 \mathrm{~kg} \mathrm{~N} /$ fed was enough to produce the highest percentages of sucrose, corrected sugar \%, quality of sugar index and corrected sugar yield in both seasons. Sara variety showed superior values over the other two varieties in LAI, root fresh weight and roots as well as tops yields $\mathrm{t} /$ fed in both seasons. While, Betamax variety attained the least values of the impurity contents in both seasons. The highest means of root weight, roots and top yields resulted from applying boron at $150 \mathrm{ppm}$ boron/fed and $100 \mathrm{~kg} \mathrm{~N} / \mathrm{fed}$ in both seasons. Foliar application of $150 \mathrm{ppm}$ boron/fed on Sara variety plants produced the highest values for root fresh weight and root yield in both seasons. Significant positive association was obtained between corrected sugar yield and root yield, leaf area index, top yield, sucrose \%, nitrogen and quality index. Corrected sugar yield was highly significantly correlated with root fresh weight and sucrose \%; while, significant negative correlation were shown between quality index and both potassium and sodium. These traits will enable the agronomists to realize high income of sugar yield in sugar beet varieties. Use of factor analysis has the potential of increasing the comprehension of the casual relationship of variables and can help to determine the nature and sequence of traits to be evaluation sugar beet varieties trails. Applying these conditions could be recommended for growing sugar beet varieties with $100 \mathrm{~kg} \mathrm{~N} /$ fed fertilization and boron application at the rate of $150 \mathrm{ppm}$ boron/fed increase roots, tops and corrected sugar yield $\mathrm{t} / \mathrm{fed}$.
\end{abstract}

Key words: Boron and Nitrogen fertilization, Sugar beet varieties, sandy soil, Correlation, Factor analysis.

\section{INTRODUGTION}

Nitrogen fertilization has a remarkable effect on sugar beet growth since it increases leaf area, root dimension, number of green leaves and root fresh weight.Thus, the economic yield of sugar beet roots which will be supplied to sugar factories will increase (Crivineanu, 1995). Whereas, much nitrogen fertilization led to increased roots yield and their impurities contents, but it reduced sucrose content in roots and consequently limits refined sucrose production (Hills and Albert, 1971). Increasing nitrogen fertilizer led to reduced sucrose content in root and increased impurities that hinder sucrose crystallization process (Stevens et al., 2007). In this regard, Kemp et al. (1994), Besheit et al. (1995) and Moustafa et al. (2000) mentioned that the drop in juice purity largely 
reflects increasing content of amino nitrogen and total soluble solids, which is caused by excessive uptake of nitrogen. Increasing nitrogen application from 50 up to $125 \mathrm{~kg} \mathrm{~N} / \mathrm{fed}$ caused significant increases in root dimensions, top and root fresh weight/plant, $\mathrm{Na} \%, \mathrm{~K} \%$, sugar lost in molasses and root yield/fed (Omar and Mohamed 2013). The highest average of sugar, purity and extractable sugar percentages were produced with using $100 \mathrm{~kg} \mathrm{~N} / \mathrm{fed}$. Abdou and Badawy (2014) and El-Geddawy and Makhlouf (2015) reported that increasing nitrogen rates from 100 to $130 \mathrm{~kg} \mathrm{~N} /$ fed significantly increased root fresh weight, root dimensions and root sugar yields/fed. However, the impurities of root contents become high. The highest average of sucrose percentage was recorded with $100 \mathrm{~kg}$ $\mathrm{N} /$ fed, while, sugar yield recorded the highest value with the rate of $120 \mathrm{~kg} \mathrm{~N} / \mathrm{fed}$.

Boron is essential for providing sugars, which are needed for root growth in all plants. In this connection, Allen et al. (2007) suggested that boron increases the rate of transport of sugars (which are produced by photosynthesis in mature plant leaves) to actively growing regions, and also in developing roots. Many attempts were conducted to determine the preferable rate of boron application to reach a good quality of sugar beet,e.g., Abo El-Hamd and Esmail (2008) and Enan (2011) found that increasing B levels up to $200 \mathrm{ppm}$ as boric acid/fed significantly improved root length, root diameter, root fresh weight/plant and sugar yield/fed. Mohamed et al. (2014) showed that increasing boron fertilizer up to $0.20 \mathrm{~g} / \mathrm{L}$ resulted in the highest recoverable sugar compared with the untreated. Sucrose, recoverable sucrose and juice purity percentages were also increased by adding high 0.20 and $0.25 \mathrm{~g} / \mathrm{L}$ levels of boron. Ali (2015) found that application of 120 and $150 \mathrm{ppm}$ boron significantly improved root yield and percentage of gross and white sugar. On the contrary $\mathrm{Na}, \mathrm{K}$, $\alpha$-amino $\mathrm{N}$ and loss of sugar percentages, decreased. Correlation analysis revealed the presence of highly significant $r$ values between root yield and gross sugar (\%). Many studies suggested the effect of combination of nitrogen and boron supplementation on yield and quality. In this respect, Ali and Shaaban (2020) studied the influence of nitrogen at three levels (190, 240 and $290 \mathrm{~kg} \mathrm{~N} \mathrm{ha}^{-1}$ and boron at $0,1.2$, and $2.4 \mathrm{~kg} \mathrm{ha}^{-1}$ ) on sugar beet grown in a sandy soil. They found that integration of $290 \mathrm{~kg} \mathrm{~N}$ ha $^{-1}$ with $1.2 \mathrm{~kg} \mathrm{~B} \mathrm{ha}^{-1}$ improved the growth, sugar yields and their quality, under semi-arid conditions. Correlation analysis showed that root yield and root fresh weight were highly significant. The varietal difference among varieties might be attributed to their genetic constituents and their capacity to advantage from the environmental factors (Hozayn, et al. 2013). In this concern, Enan et al. (2016) found that Polat variety surpassed Natoura and Henrike varieties, which recorded the maximum values of root diameter, fresh and top weights/plant as well as top yield/fed. Aly et al. (2017) results indicated that Karim variety had the highest values in leaf area index (LAI), root and foliage fresh weighs (g/plant), as well as root and extracted sugar yields ( $\mathrm{t} / \mathrm{fed})$. Meantime, Nancy surpassed Karim in sucrose \%, extracted sugar\% and quality index $\%$.

The present study was performed to evaluate the effect of nitrogen and boron fertilization levels on the yield and quality of sugar beet varieties performances under sandy soil conditions.

\section{MATERIALS AND METHODS}

Two field experiments were carried out at ElNubaria (latitude of $30^{\circ} 38 / \mathrm{N}$, longitude of $42^{0}$ $01 / \mathrm{E}$, and elevation of $33 \mathrm{~m}$ above sea level), El-Buhira Governorate, Egypt, during $2017 / 2018$ and $2018 / 2019$ seasons to study the effect of two foliar applications $(0$ and $150 \mathrm{ppm}$ Boron/fed) and three nitrogen fertilization rates $(80,100$ and $120 \mathrm{~kg} \mathrm{~N} / \mathrm{fed})$ on the yield, growth and quality of some sugar beet varieties, i.e. Sara (E-type, Nederland),Dena ( $N$-type, Nederland) and Betamax ( $Z$ type, France). The two foliar applications of boron were applied as zero (control= check treatment) and $150 \mathrm{ppm} \mathrm{B/fed} \mathrm{as}$ (boric acid 17\% B). A split-split plot design with three replicates was used, where boron foliar treatments were placed in the main plots, while nitrogen fertilization treatment were placed in sub plots, where the sub-sub plots were randomly planted with the three sugar beet varieties, with three replications. Each experimental basic Ppot area was $15 \mathrm{~m}^{2}$ (1/280 fed) including five ridges of $60-\mathrm{cm}$ width and 5$\mathrm{m}$ length, each. The preceding summer crops were maize. Sugar beet seeds was planted on the $1^{\text {st }}$ week of October in both seasons and harvested after 210 days from sowing date.

Calcium superphosphate $\left(15.0 \% \quad \mathrm{P}_{2} \mathrm{O}_{5}\right)$ was applied during soil preparation at the rate of 200 $\mathrm{kg} /$ fed. Potassium sulfate $\left(48 \% \mathrm{~K}_{2} \mathrm{O}\right)$ at the rate of $50 \mathrm{~kg} / \mathrm{fed}$ was applied with the second nitrogen dose. 
Nitrogen fertilizer in the form of ammonium nitrate $(33.5 \% \mathrm{~N})$ was added in three equal doses, after thinning and at 3-week intervals later. Boron was sprayed as Boric acid (17\% B) in two equal doses at the age of 60 and 75 days after sowing. Soil samples were taken before sowing at random from every location area at a depth of 0-30 $\mathrm{cm}$ from soil surface and prepared for mechanical and chemical analysis. Properties for the experimental soil determined according to Piper (1955) are illustrated in Table (1). Other agricultural practices were applied as recommended for growing sugar beet in the region.
D. Impurities of juice, in terms of Sodium (Na) and Potassium $(\mathrm{K})$ concentrations were estimated as meq $/ 100 \mathrm{~g}$ beet according to the procedures of Sugar Company, by Automated Analyzer, as described by Brown and Lilliand (1964). Alpha-amino-N was determined using Hydrogenation method according to Carruthers et al. (1962).

At harvest, sugar beets of three ridges from all sub-sub plots were uprooted, topped and weighed to determine the following parameters:

1. Top yield $(\mathrm{t} / \mathrm{fed})$.

2. Root yield ( $\mathrm{t} / \mathrm{fed})$.

3. Corrected sugar yield $(t / f e d)$, which was

Table (1): Particle size distribution and some chemical properties of the soil of the experimental site in 2017/2018and 2018/2019 seasons.

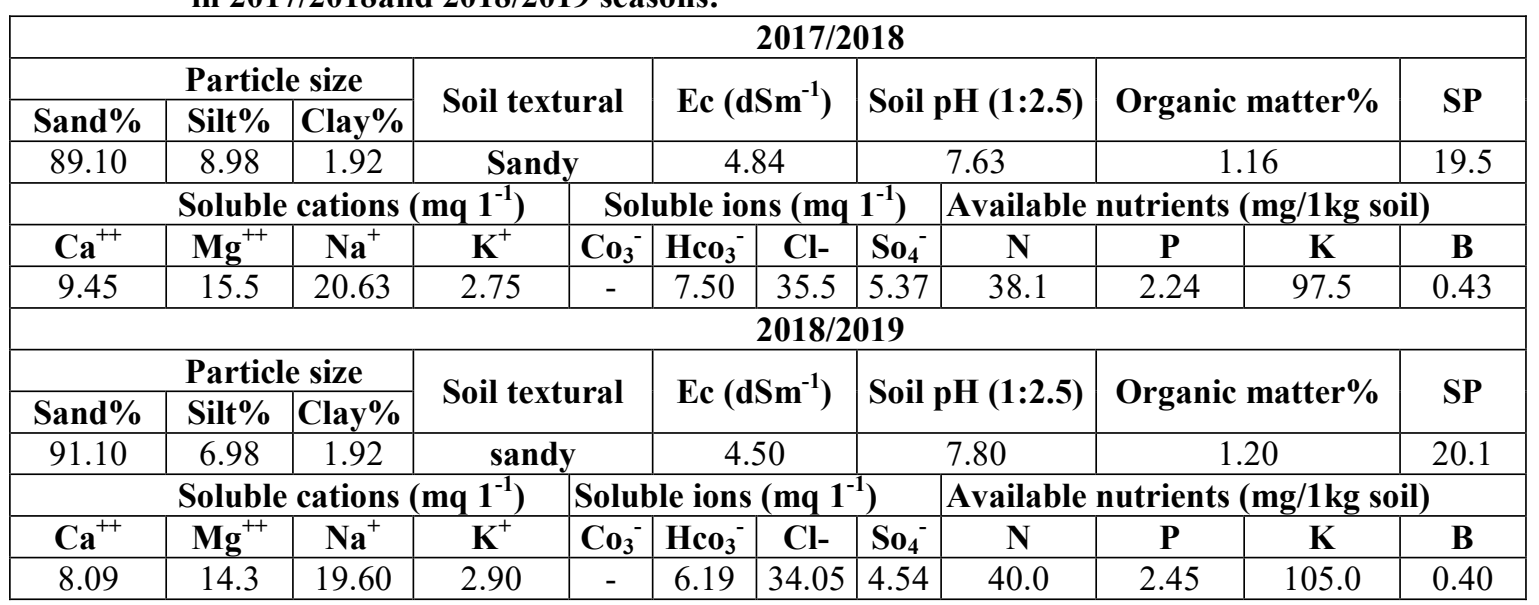

\subsection{The recorded data}

LAI $=$ Leaf area/plant $\left(\mathrm{cm}^{2}\right) /$ plant ground area $\left(\mathrm{cm}^{2}\right)$ was measured at 120 days from sowing date using the leaf area meter, model: $3000 \mathrm{~A}$

At harvest, a sample of five plants was randomly collected from each treatment,and cleaned to determine the following characters:

1- Root fresh weight (g/plant),

2- Quality traits were determined in Beet Sugar Laboratory at Alexandria Sugar Factory, Egypt.

A. Sucrose percentage (Pol \%) was estimated in fresh samples of sugar beet roots, using Saccharometer according to the method described in A.O.A.C (2005).

B. Corrected sugar \% was calculated using the following equation according to Rainfeld (1974):

Corrected sugar $\%=$ Pol $\%-0.343(\mathrm{~K}+\mathrm{Na})$

$-\alpha$-amino N (0.0939) - 0.29.

C. Juice quality index (QI\%) was calculated according to Rainfeld et al. (1974) using the following equation: $\mathrm{QI} \%=$ Corrected sugar $\%$ X 100/ Pol \%. calculated according to the following equation: Corrected sugar yield $(\mathrm{t} / \mathrm{fed})=$ roots yield (ton/fed) x corrected sugar $\%$.

\subsection{Statistical analysis}

All obtained data were statistically analyzed according to (MSTAT-C) computer software package. Least significant differences (LSD) method was used to test the differences between treatment means at 5\% level of probability as described by Snedecor and Cochran (1981).

Simple correlation: a matrix of simple correlation coefficients between sugar yield and each of its components were computed as applied by Steel and Torrie (1980).

Factor analysis: this statistical approach was applied according to Cattell (1965) to reduce a large number of correlated variables to a much smaller No. of independent clusters of variables called factors. After loading of the first factor was calculated, the process was repeated on the residuals matrix to find further factors. When the contribution of a factor to the total percentage of the trace was less than $10 \%$, the process was 
stopped. After extraction, the matrix of factor loadings was submitted to a varimax orthogonal rotation, as applied by Kaiser (1958). The purpose of rotation was to rebuilding the larger loadings in each factor and to suppress the minor loading coefficient to improve the opportunity of achieving meaningful biological interpretation of each factor.

\section{RESULTS AND DISCUTION}

The obtained results in Table (2), clear that fertilizing sugar beet plants with $150 \mathrm{ppm}$ boric acid/fed recorded a significant increase in values of root fresh weight $(\mathrm{kg})$ and root yield (ton), while leaf area index and top yield recorded insignificant raise in both seasons compared to control. Therefore, the important roles of boron on root dimension and foliage development could be attributed to the stimulant effect on rate of photosynthesis through carbohydrate metabolism and transport of the photosynthetic product from the leaves to the storage root. These results may be due to the fact that the foliar application by $150 \mathrm{ppm} \mathrm{B/fed} \mathrm{significantly}$ increased LAI and root fresh weight, which may nitrogen fertilization was not reached at the level $5 \%$ of significance. Addition of $100 \mathrm{~kg} \mathrm{~N} / \mathrm{fed}$ resulted in a significant increase amounted to (0.16 and 0.12$),(0.017$ and $0.016 \mathrm{~kg}),(1.42$ and 1.63 tons) and by ( 0.70 and 0.68 tons) in LAI, root fresh weight, yield of root and top $t / f e d$ in the first and second seasons compared with plots treated with $80 \mathrm{~kg} \mathrm{~N} / \mathrm{fed}$, respectively. These results may be attributed to the nitrogen and $\mathrm{N}$ role in excessive vegetative growth. These results are in harmony with these obtained by Abdou and Badawy (2014) and El-Geddawy and Makhlouf (2015).

Presented data in Table (2), revealed significant differences among sugar beet varieties in LAI, root fresh weight and roots as well as top yields $\mathrm{t} / \mathrm{fed}$ in the $1^{\text {st }}$ and the $2^{\text {nd }}$ seasons. Sara variety showed the superiority over the other two varieties in all respect of the previous traits in both seasons. The variations among the tested sugar beet varieties in these traits might be due to their gene makeup. These observations coincide with those found by Hozayn, et al. (2013) and Aly et al., (2017).

Results in Table (3) showed that sucrose \%

Table (2): Leaf area index (LAI), root fresh weight (kg), root and top yields (t/fed) affected by nitrogen and boron applications on three sugar beet varieties in 2017/18 and 2018/19 seasons.

\begin{tabular}{|c|c|c|c|c|c|c|c|c|}
\hline \multirow{2}{*}{ Treatments } & \multicolumn{2}{|c|}{ LAI } & \multicolumn{2}{|c|}{ Root fresh weight (kg) } & \multicolumn{2}{|c|}{ Root yield ( $t /$ fed) } & \multicolumn{2}{|c|}{ Top yield (t/fed) } \\
\hline & 2017/18 & 2018/19 & $2017 / 18$ & 2018/19 & 2017/18 & 2018/19 & 2017/18 & 2018/19 \\
\hline \multicolumn{9}{|c|}{ Boron foliar application levels } \\
\hline Without boron & 3.34 & 3.45 & 1.078 & 1.103 & 24.70 & 24.79 & 9.05 & 9.32 \\
\hline $150 \mathrm{ppm} \mathrm{B} / \mathrm{fed}$ & 3.39 & 3.50 & 1.124 & 1.131 & 25.17 & 25.34 & 9.20 & 9.56 \\
\hline F. Test & ns & ns & * & * & * & $*$ & ns & ns \\
\hline \multicolumn{9}{|c|}{ Nitrogen soil application levels } \\
\hline $80 \mathrm{~kg} \mathrm{~N} / \mathrm{fed}$ & 3.24 & 3.39 & 1.047 & 1.074 & 23.90 & 23.96 & 8.58 & 8.95 \\
\hline $100 \mathrm{~kg} \mathrm{~N} / \mathrm{fed}$ & 3.40 & 3.51 & 1.118 & 1.135 & 25.32 & 25.59 & 9.28 & 9.63 \\
\hline $120 \mathrm{~kg} \mathrm{~N} / \mathrm{fed}$ & 3.47 & 3.52 & 1.138 & 1.141 & 25.59 & 25.65 & 9.52 & 9.74 \\
\hline LSD at 0.05 & 0.07 & 0.10 & 0.026 & 0.031 & 0.43 & 0.42 & 0.17 & 0.31 \\
\hline \multicolumn{9}{|c|}{ Sugar beet varieties } \\
\hline Betamax & 3.12 & 3.18 & 0.943 & 0.959 & 23.16 & 23.30 & 7.89 & 8.29 \\
\hline Dena & 3.38 & 3.46 & 1.098 & 1.119 & 24.94 & 24.97 & 9.08 & 9.37 \\
\hline Sara & 3.61 & 3.79 & 1.262 & 1.273 & 26.71 & 26.92 & 10.41 & 10.66 \\
\hline LSD at 0.05 & 0.05 & 0.09 & 0.026 & 0.028 & 0.40 & 0.37 & 0.20 & 0.20 \\
\hline
\end{tabular}

have increased the photosynthetic surface per unit area, which consequently promoted growth and nutrient uptake of plants by addition of boron which affects walls membrane. These results are in agreement with Aly et al. (2017).

The difference between 100 and $80 \mathrm{~kg} \mathrm{~N} /$ fed was significant at $5 \%$ probability on LAI, root fresh weight and yields of roots and top/fed in the $1^{\text {st }}$ and the $2^{\text {nd }}$ seasons respectively, while the difference between 120 and $100 \mathrm{~kg} \mathrm{~N} / \mathrm{fed}$ was considerablly affected by boron foliar application in both seasons. However, foliar application with boron significantly affected the root contents of impurities $(\mathrm{Na}, \mathrm{K}$ and alpha amino-N) compared to without boron application in the $2^{\text {nd }}$ only. The increase of sucrose $\%$ in sugar beet root referred to the actively role of boron in carbohydrate translocation from source as leaf to sink as roots Allen et al. (2007). 
Fertilizing sugar beet plants with $100 \mathrm{~kg}$ $\mathrm{N} /$ fed was enough to produce the highest percentage of sucrose in beet root, without any significant variation with those applied at $120 \mathrm{~kg}$ $\mathrm{N} / \mathrm{fed}$, in both seasons. In the same Table, fertilizing with $80 \mathrm{~kg} \mathrm{~N} /$ fed recorded the least significant variance with 100 and/or $120 \mathrm{~kg}$ $\mathrm{N} /$ fed for $\mathrm{K}$ and Alpha amino-N in both seasons; however, insignificant variance was observed in $\mathrm{Na}$ trait in both seasons. These results are in harmony with those obtained Mohamed et al. (2014) and Ali (2015) who concluded that foliar application with boron increasing sucrose and purity percentages accompanied by decrease the impurities contents in sugar beet roots.

Data in Table (3) manifested those differences among the three sugar beet varieties in all traits in both seasons. The variety Betamax showed the superiority over the other two sugar index and corrected sugar yield (ton/fed) compared with the check treatment in both seasons. These finding are in agreement with those mentioned by Ali (2015) and Ali and Shaaban (2020).

Corrected sugar \%, quality sugar index (QI\%) and corrected sugar yield in the same table considerably increased enough as the applied nitrogen levels raised from $80 \mathrm{~kg}$ up to $100 \mathrm{~kg}$ $\mathrm{N} /$ fed in both seasons, as well as QI only in the $2^{\text {nd }}$ season. Application with the rate of $100 \mathrm{~kg} \mathrm{~N} / \mathrm{fed}$ resulted in the highest values of these traits compared with 80 and/or $120 \mathrm{~kg} \mathrm{~N} / \mathrm{fed}$. These results assured the importance role of nitrogen element in metabolic process and the injury of the excessive amount of it on juice purity of sugar beet process. The positive effect of nitrogen effect of nitrogen element on sucrose, corrected sugar percentages and correct sugar yield/fed treatments

Table (3): Sucrose\% and impurities ( $\mathrm{Na}, \mathrm{K}$ and $\alpha$ - amino- $\mathrm{N}$ meq./100 g beet) traits affected by nitrogen and boron applications on three sugar beet varieties in 2017/18 and 2018/19 seasons.

\begin{tabular}{|c|c|c|c|c|c|c|c|c|}
\hline \multirow{3}{*}{$\mathrm{C}_{\text {Treatments }}^{\text {Traits }}$} & \multirow{2}{*}{\multicolumn{2}{|c|}{ Sucrose\% }} & \multicolumn{6}{|c|}{ Impurities (meq./100 g beet) } \\
\hline & & & \multicolumn{2}{|c|}{$\mathrm{Na}$} & \multicolumn{2}{|c|}{ K } & \multicolumn{2}{|c|}{$\alpha-\operatorname{amino} \mathbf{N}$} \\
\hline & $2017 / 18$ & 2018/19 & $2017 / 18$ & 2018/19 & 2017/18 & 2018/19 & $2017 / 18$ & $2018 / 19$ \\
\hline \multicolumn{9}{|c|}{ Boron foliar application levels } \\
\hline without Boron & 18.61 & 18.48 & 2.22 & 2.35 & 3.30 & 3.38 & 0.64 & 0.61 \\
\hline $150 \mathrm{ppm} \mathrm{B} / \mathrm{fed}$ & 19.36 & 19.00 & 2.12 & 2.12 & 3.11 & 3.17 & 0.57 & 0.53 \\
\hline F. Test & $*$ & $*$ & ns & $*$ & ns & $*$ & ns & $*$ \\
\hline
\end{tabular}

\begin{tabular}{|c|c|c|c|c|c|c|c|c|}
\hline \multicolumn{9}{|c|}{ Nitrogen soil application levels } \\
\hline $80 \mathrm{~kg} \mathrm{~N} /$ fed & 18.30 & 18.12 & 2.21 & 2.31 & 3.06 & 3.26 & 0.47 & 0.46 \\
\hline $100 \mathrm{~kg} \mathrm{~N} /$ fed & 19.34 & 19.20 & 2.14 & 2.24 & 3.25 & 3.26 & 0.61 & 0.58 \\
\hline $120 \mathrm{~kg} \mathrm{~N} / \mathrm{fed}$ & 19.32 & 18.91 & 2.15 & 2.15 & 3.30 & 3.30 & 0.72 & 0.68 \\
\hline LSD at 0.05 & 0.28 & 0.15 & ns & Ns & 0.15 & $\mathbf{0 . 0 8}$ & 0.04 & $\mathbf{0 . 0 3}$ \\
\hline \multicolumn{9}{|c|}{ Sugar beet varieties } \\
\hline Betamax & 19.69 & 19.35 & 1.98 & 2.06 & 3.05 & 3.15 & 0.53 & 0.50 \\
\hline Dena & 19.10 & 18.83 & 2.23 & 2.28 & 3.20 & 3.25 & 0.57 & 0.56 \\
\hline Sara & 18.17 & 18.05 & 2.30 & 2.37 & 3.35 & 3.42 & 0.70 & 0.67 \\
\hline LSD at 0.05 & 0.18 & 0.14 & 0.12 & 0.09 & 0.15 & 0.10 & 0.03 & 0.03 \\
\hline
\end{tabular}

varieties in respect of sucrose \% in both seasons; however, the variety attained the lowest values in respect of the impurity contents in sugar beet roots (Na, K and Alpha amino-N) in both seasons. Those variations among the tested sugar beet varieties might be due to their gene make-up. These observations coincide with those found by Hozayn et al. (2013) and Aly et al. (2017).

Results in Table (4) cleared that foliar application with $150 \mathrm{ppm}$ boron/fed had a significant effect on corrected sugar $\%$, quality was reported by Hills and Albert (1971), Stevens et al. (2007) and Omar and Mohamed (2013).

Results in Table (4) indicated significant differences among the three tested varieties in corrected sugar $\%$, QI and corrected sugar yield in both seasons. The variety Betamax recorded the highest values corrected sugar \% and QI in both seasons. Sara variety gave the highest corrected sugar yield in both seasons. However, insignificant differences were found between Sara and Dina varieties in the $1^{\text {st }}$ season only for corrected sugar yield. These results are in line 
Table (4): Corrected sugar \%, quality index (QI) and corrected sugar yield ( $t /$ fed) affected by nitrogen and Boron applications on three sugar beet varieties in 2017/18 and 2018/19 seasons.

\begin{tabular}{|c|c|c|c|c|c|c|}
\hline \multirow{2}{*}{$\mathrm{P}_{\text {Treatments }}$ Traits } & \multicolumn{2}{|c|}{ Corrected sugar\% } & \multicolumn{2}{|c|}{ QI\% } & \multicolumn{2}{|c|}{$\begin{array}{c}\text { Corrected sugar yield } \\
(t / \text { fed })\end{array}$} \\
\hline & $2017 / 18$ & 2018/19 & $2017 / 18$ & 2018/19 & $2017 / 18$ & 2018/19 \\
\hline \multicolumn{7}{|c|}{ Boron foliar application levels } \\
\hline Without boron & 16.37 & 16.17 & 87.92 & 87.45 & 4.04 & 4.00 \\
\hline 150 ppm B/fed & 17.22 & 16.85 & 88.93 & 88.63 & 4.32 & 4.26 \\
\hline F. Test & $*$ & $*$ & $*$ & $*$ & $*$ & $*$ \\
\hline \multicolumn{7}{|c|}{ Nitrogen soil application levels } \\
\hline $80 \mathrm{~kg} \mathrm{~N} / \mathrm{fed}$ & 16.16 & 15.87 & 88.27 & 87.57 & 3.86 & 3.80 \\
\hline $100 \mathrm{~kg} \mathrm{~N} /$ fed & 17.14 & 16.97 & 88.61 & 88.36 & 4.33 & 4.34 \\
\hline $120 \mathrm{~kg} \mathrm{~N} / \mathrm{fed}$ & 17.09 & 16.68 & 88.40 & 88.19 & 4.35 & 4.27 \\
\hline LSD at 0.05 & 0.31 & 0.16 & ns & 0.34 & 0.10 & 0.09 \\
\hline \multicolumn{7}{|c|}{ Sugar beet varieties } \\
\hline Betamax & 17.62 & 17.23 & 89.49 & 89.01 & 4.08 & 4.02 \\
\hline Dena & 16.89 & 16.59 & 88.41 & 88.09 & 4.21 & 4.14 \\
\hline Sara & 15.87 & 15.71 & 87.37 & 87.03 & 4.25 & 4.24 \\
\hline LSD at 0.05 & 0.20 & 0.13 & $\mathbf{0 . 3 3}$ & 0.25 & 0.08 & 0.08 \\
\hline
\end{tabular}

with those reported by Hozayn et al. (2013) and Aly et al. (2017).

Data in Table (5) clear that the interaction between boron foliar applications with nitrogen levels soil application had a significant effect on all traits in this table. The highest means root weight (1.149 and $1.167 \mathrm{~kg})$, root yield (25.81 and 26.00 tons/fed) and top yield (9.52 and 9.92 tons/fed) resulted from applied boron on sugar beet plants by $150 \mathrm{ppm}$ boron/fed and $100 \mathrm{~kg}$ $\mathrm{N} /$ fed in both seasons, respectively. The highest sucrose \% (19.95\%) resulted from boron (150 ppm) and (120 kg N/fed) in the $1^{s t}$ season and (19.34\%) resulted from $150 \mathrm{ppm}$ boron and fertilized sugar beet plants by $100 \mathrm{~kg} \mathrm{~N} / \mathrm{fed}$ in the $2^{\text {nd }}$ season.

Corrected sugar \% was highest with fertilized sugar beet plants by $120 \mathrm{~kg} \mathrm{~N} / \mathrm{fed}$ and $150 \mathrm{ppm}$ of boron in the $1^{\text {st }}$ season, while in the $2^{\text {nd }}$ season the highest corrected sugar \% resulted from growing sugar beet plants under foliar application with $150 \mathrm{ppm}$ boron and $100 \mathrm{~kg}$ $\mathrm{N} / \mathrm{fed}$. These results are agreement with those obtained by Ali (2015) and Ali and Shaaban (2020).

The results in Table 6 showed the interaction between foliar boron applications $\mathrm{x}$ sugar beet varieties. Sara variety produced the highest mean values for root fresh weight and root yield in both seasons and corrected sugar yield in the $2^{\text {nd }}$ seasons only when applied by $150 \mathrm{ppm}$ boron/fed compared with the other tested varieties. Meanwhile, the variety Betamax produced significantly higher values only in the $2^{\text {nd }}$ season compared to the Dena and/or Sara varieties for sucrose and correct sugar $\%$.

All the other interactions un-tabulated as $\mathrm{N} \mathrm{x}$ $\mathrm{V}$ and $\mathrm{B} \times \mathrm{N} \times \mathrm{V}$ were insignificant effect on all traits under this study.

\subsection{Simple correlation matrix}

Correlation coefficients between all pairs of studied traits are shown in Table (7). The results revealed that there was a highly significant positive correlation between sugar yield and each of root yield $\left(0.728^{* *}\right)$, top yield $\left(0.644^{* *}\right)$, leaf area index $\left(0.498^{* *}\right)$, sucrose $\%\left(0.483^{* *}\right)$, nitrogen $\left(0.464^{* *}\right)$ and quality index $\left(0.320^{* *}\right)$. The data cleared that significant positive correlation between sugar yield and root fresh weight $\left(0.551^{*}\right)$. There was highly significant positive correlation between quality and sucrose $\left(0.809^{* *}\right)$ while, highly significant negative orrelation were observed between quality index and each of potassium $(-0.740 * *)$ and sodium $\left(-.698^{* *}\right)$. Accordingly, the breeder should exploit the previous traits to achieve high sugar yield of sugar beet. However, insignificant associations previous traits to achieve high sugar yield of sugar beet. However, insignificant associations were observed between sugar yield and each of potassium and sodium reducing sugar indicating that these traits may be independent in their genetic expression under the resent study. The sugar agronomists must take into account the interrelationships among the sugar yield components when planning the farming program. 
Table (5): The interaction effect between boron and nitrogen application on some traits during 2017/18 and 2018/19 seasons.

\begin{tabular}{|c|c|c|c|c|c|c|c|c|c|c|c|}
\hline \multirow{2}{*}{\multicolumn{2}{|c|}{$\begin{array}{c}\text { Boron x } \\
\text { Nitrogen } \\
\text { levels } \\
\text { interaction } \\
\end{array}$}} & \multicolumn{2}{|c|}{$\begin{array}{c}\text { Root fresh weight } \\
(\mathrm{kg})\end{array}$} & \multicolumn{2}{|c|}{ Root yield (t/fed) } & \multicolumn{2}{|c|}{ Top yield (t/fed) } & \multicolumn{2}{|c|}{ Sucrose\% } & \multicolumn{2}{|c|}{$\begin{array}{c}\text { Corrected } \\
\text { sugar } \%\end{array}$} \\
\hline & & $2017 / 18$ & 2018/19 & $2017 / 18$ & 2018/19 & $2017 / 18$ & 2018/19 & $2017 / 18$ & 2018/19 & $2017 / 18$ & 2018/19 \\
\hline \multirow{3}{*}{ B1 } & N1 & 1.014 & 1.046 & 23.54 & 23.47 & 8.50 & 8.87 & 17.98 & 17.80 & 15.79 & 15.52 \\
\hline & N2 & 1.087 & 1.104 & 24.82 & 25.19 & 9.03 & 9.35 & 19.16 & 19.07 & 16.93 & 16.76 \\
\hline & N3 & 1.133 & 1.158 & 25.73 & 25.71 & 9.61 & 9.75 & 18.68 & 18.58 & 16.37 & 16.24 \\
\hline \multirow{3}{*}{ B2 } & N1 & 1.080 & 1.102 & 24.25 & 24.45 & 8.66 & 9.04 & 18.61 & 18.44 & 16.52 & 16.23 \\
\hline & $\mathbf{N 2}$ & 1.149 & 1.167 & 25.81 & 26.00 & 9.52 & 9.92 & 19.51 & 19.34 & 17.35 & 17.19 \\
\hline & N3 & 1.142 & 1.124 & 25.45 & 25.58 & 9.43 & 9.73 & 19.95 & 19.23 & 17.81 & 17.13 \\
\hline \multicolumn{2}{|c|}{ LSD at $5 \%$} & 0.037 & 0.043 & 0.60 & 0.59 & 0.23 & 0.31 & 0.40 & 0.21 & 0.43 & 0.23 \\
\hline
\end{tabular}

$B 1=$ control treatment, $B 2=150 \mathrm{ppm}$ Boron/fed as foliar application; N1, N2 and N3 = 80, 100 and $120 \mathrm{~kg} N /$ fed as soil application.

Table (6): Significant interactions between boron levels and sugar beet varieties of some traits in two growing seasons $2017 / 18$ and $2018 / 19$.

\begin{tabular}{|c|c|c|c|c|c|c|c|c|}
\hline \multirow{2}{*}{\multicolumn{2}{|c|}{$\begin{array}{c}\text { Boron } x \\
\text { varieties } \\
\text { interaction }\end{array}$}} & \multicolumn{2}{|c|}{$\begin{array}{c}\text { Root fresh weight } \\
\text { (kg) }\end{array}$} & \multicolumn{2}{|c|}{ Root yield (t/fed) } & \multirow{2}{*}{$\begin{array}{c}\text { Sucrose\% } \\
2018 / 19 \\
\end{array}$} & \multirow{2}{*}{$\begin{array}{c}\begin{array}{c}\text { Corrected } \\
\text { sugar\% }\end{array} \\
2018 / 19 \\
\end{array}$} & \multirow{2}{*}{$\begin{array}{c}\begin{array}{c}\text { Corrected } \\
\text { sugar yield } \\
\text { (t/fed) }\end{array} \\
2018 / 19 \\
\end{array}$} \\
\hline & & $2017 / 18$ & 2018/19 & $2017 / 18$ & 2018/19 & & & \\
\hline \multirow{3}{*}{ B1 } & Betamax & 0.909 & 0.935 & 22.91 & 22.95 & 19.23 & 17.04 & 3.92 \\
\hline & Dena & 1.098 & 1.113 & 25.05 & 25.03 & 18.55 & 16.23 & 4.06 \\
\hline & Sara & 1.228 & 1.260 & 26.13 & 26.39 & 17.66 & 15.25 & 4.03 \\
\hline \multirow{3}{*}{ B2 } & Betamax & 0.977 & 0.984 & 23.40 & 23.66 & 19.47 & 17.41 & 4.13 \\
\hline & Dena & 1.098 & 1.124 & 24.82 & 24.92 & 19.10 & 16.95 & 4.22 \\
\hline & Sara & 1.296 & 1.286 & 27.29 & 27.46 & 18.43 & 16.17 & 4.44 \\
\hline \multicolumn{2}{|c|}{ LSD at $5 \%$} & 0.037 & 0.040 & 0.56 & 0.52 & 0.20 & 0.19 & 0.11 \\
\hline
\end{tabular}

B1= zero treatment, B2= $150 \mathrm{ppm}$ Boron/fed as foliar.

Table (7): Simple correlation coefficient among sugar yield and its components in sugar beet over $2017 / 18$ and $2018 / 19$ seasons.

\begin{tabular}{|l|c|c|c|c|c|c|c|c|c|c|}
\hline \multicolumn{1}{|c}{ Traits } & RFW & LAI & TY & Sucrose\% & Na & K & N & QI & RY & CSY \\
\hline RFW & 1 & $\begin{array}{c}0.810^{*} \\
*\end{array}$ & $0.873^{* *}$ & -0.302 & 0.335 & 0.133 & 0.486 & -0.352 & $0.847^{* *}$ & $0.551^{*}$ \\
\hline LAI & & 1 & $0.800^{* *}$ & -0.272 & 0.539 & 0.142 & $0.504^{*}$ & -0.358 & $0.733^{* *}$ & $0.498^{* *}$ \\
\hline TY & & & 1 & -0.202 & 0.365 & -0.035 & $0.594^{*}$ & -0.254 & $0.869^{* *}$ & $0.644^{* *}$ \\
\hline Sucrose \% & & & & 1 & -0.346 & -0.467 & -0.087 & $0.809^{* *}$ & -0.241 & $0.483^{* *}$ \\
\hline Na & & & & & 1 & 0.231 & 0.454 & $-0.698^{* *}$ & 0.364 & 0.021 \\
\hline K & & & & & & 1 & -0.033 & $-0.740^{* *}$ & 0.105 & -0.291 \\
\hline N & & & & & & & 1 & -0.278 & $0.615^{* *}$ & $0.464^{* *}$ \\
\hline QI & & & & & & & & 1 & -0.334 & $0.320^{* *}$ \\
\hline RY & & & & & & & & & 1 & $0.728^{* *}$ \\
\hline CSY & & & & & & & & & & 1 \\
\hline
\end{tabular}

* and ** significant at 0.05 and 0.01 probability levels, respectively.

RFW: Root fresh weight, LAI: leaf area index, TY: Top yield t/fed, SUC: Sucrose \%, Na: Sodium, K: Potassium, QI: Quality index\%; RY: Root yield (t/fed) and CSY: Corrected sugar yield (t/fed).

It is worthwhile to state that the large sample size $(n=144)$ of data may be a reason of the significance of some small values of correlation coefficients. The present results are similar to those reported by Ghareeb et al. (2013). 


\subsection{Factor analysis}

The factor analysis technique divided the nine sugar yield components into two independent groups or factors, which explained $74.75 \%$ of the total variability in the dependence structure. The factors were constructed by applying the principal component approach to establish the dependent relationship between sugar yield attribute in sugar beet. Factor loadings that greater than 0.5 were considered important. A summary of the composition of variables of the two extracted factors with loading are given in Table (8).
With the screen test, we ploted the eigen values associated with each component and look ed for a "break" between the components with relatively large Eigen values and those with small eigen values. The components that appear the break before the break are assumed to be more meaningful (Fig. 1). The higher loading displaying variables on first factor (six traits) were root diameter, root fresh weight, leaf area index, top yield, and nitrogen and root yield (Table 8).

Table (8): Summary of factor loadings for the ten traits of sugar beet.

\begin{tabular}{|c|c|c|c|c|c|}
\hline Variables & Loading & Communality & Eigen values & $\%$ of variance & $\begin{array}{c}\text { Suggested factor } \\
\text { name }\end{array}$ \\
\hline $\begin{array}{l}\text { Factor I } \\
\text { Root fresh weight } \\
\text { Leaf area index } \\
\text { Sodium } \\
\text { Nitrogen } \\
\text { Top yield } \\
\text { Root yield }\end{array}$ & $\begin{array}{l}0.871 \\
0.846 \\
0.622 \\
0.665 \\
0.855 \\
0.874 \\
\end{array}$ & $\begin{array}{l}0.830 \\
0.775 \\
0.483 \\
0.521 \\
0.903 \\
0.863\end{array}$ & 51.107 & 44.73 & $\begin{array}{l}\text { Growth \& } \\
\text { nitrogen } \\
\text { factor }\end{array}$ \\
\hline $\begin{array}{l}\text { Factor II } \\
\text { Sucrose \% } \\
\text { Potassium } \\
\text { Quality }\end{array}$ & $\begin{array}{c}0.651 \\
-0.754 \\
0.742 \\
\end{array}$ & $\begin{array}{c}0.683 \\
0815 \\
0.990 \\
\end{array}$ & 23.546 & 29.92 & $\begin{array}{l}\text { Sugar \& quality } \\
\text { factor }\end{array}$ \\
\hline Cumulative variance & & & 74.65 & & \\
\hline
\end{tabular}

- Extraction method: principal component analysis.

- Rotation method: varimax with Keiser normalization.

Factor I included six variables which accounted for $44.73 \%$ of the total variability. The six variables were root fresh weight, leaf area index, sodium, nitrogen, top yield and root yield. It contains the variables usually regarded as a growth factor. The six variables had high communality with factor I. Therefore, this factor may be called growth and nitrogen factor.

Factor II was responsible for $29.92 \%$ of the total variability in the dependence structure. It included three traits namely, sucrose \%, potassium and quality. The sign of the loading values indicates the direction of the relationship between the factor and its related traits. So, the negative sign of the sucrose and quality indicate the negative correlation coefficients with each of the other two variables in factor II. Therefore, this factor may be called sugar and quality factor. These results were in agreement with Ghareeb et al. (2013) and Seiller and Stafford (1985).

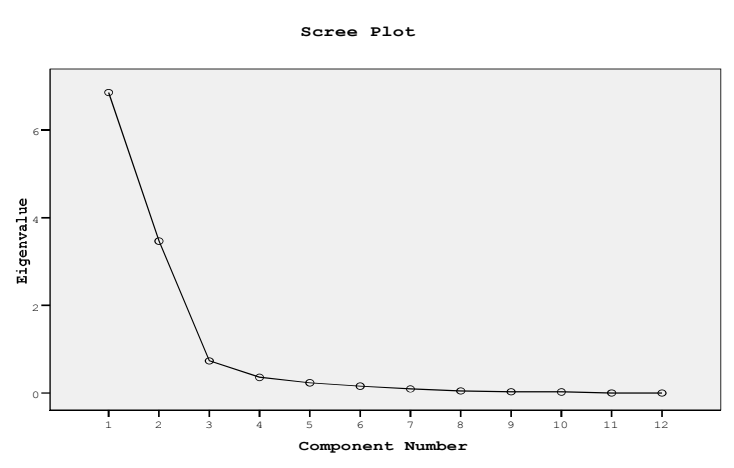

Fig. (1): Eigen values corresponding to different factors components.

Finally, it could be recommended from the previous results that, the important traits overall statistical procedures of analysis were root fresh weight, top yield and root yield in factor I. The quality variable had high communality with factor II. These traits will enable the agronomists 
to realize high income of sugar yield in sugar beet varieties. Use of factor analysis by plant breeders has the potential of increasing the comprehension of the casual relationship of variables and can help to determine the nature and sequence of traits to be selected in a breeding program or evaluation sugar beet varieties trails.

\section{Conclusion}

Under these conditions of work, it could be recommended that growing sugar beet varieties with fertilization of $100 \mathrm{~kg} \mathrm{~N} / \mathrm{fed}$ and boron application at the rate of $150 \mathrm{ppm}$ boron/fed increases roots, tops and corrected sugar yield $\mathrm{t} /$ fed. Sara variety plants gave the highest values of root and corrected sugar yield when applied by $150 \mathrm{ppm}$ boron/fed. Factor analysis grouped the studied nine traits as sugar yield components into two main factors accounting for $74.65 \%$ of the total variability in the dependence structure. Factor I included six variables which accounted for $44.73 \%$ of the total variability. The six variables were root fresh weight, leaf area index, sodium, nitrogen, top yield and root yield. It contains the variables usually regarded as a growth factor. The six variables had high communality with factor I. Therefore, this factor may be called growth and nitrogen factor. Factor II was responsible for $29.92 \%$ of the total variability in the dependence structure. It included three traits namely: sucrose $\%$, potassium and quality.

\section{REFRENCES}

A.O.A.C. (2005). Association of Official Analytical Chemists. Official Methods of Analysis, 26 $6^{\text {th }}$ Ed. AOAC International, Washington, D.C; USA.

Abdou M.A. and Badawy A.S. (2014). Sugar beet productivity and quality as affected by nitrogen fertilizer levels and irrigation withholding date. Minufiya J. Agric. Res., 39(1): 181-189.

Abo EL-Hamd A.S. and Esmail A.A. (2008). Effect of foliar potassium, magnesium and boron on yield and quality of sugar beet (Beta vulgaris, L.) growing in new reclaimed soils. J. Agric. Sci. Mansoura Univ., 33: 1737-1746

Ali A.A.M. (2015). Sugar beet productivity as affected by nitrogen fertilizer and foliar spraying with boron. Int'l. J. Curr. Microbiol. App. Sci., 4(4): 181-196.

Ali A.A.M. and Shabaan A. (2020). Integrative applications on nitrogen, zinc and boron to nutrients deficient soil improves sugar beet productivity and technological sugar contents under semi arid conditions. J. plant Nutri., 43(10):1-6.

Allen V., David J. and Pilbeam Ed. (2007). Hand Book of Plant Nutrition. (Books in Soils, plants and the environment). Boron by Umesh C. Gpta. (p. 241-278).

Aly E.F.A., Khalil Soha R. and Abdel Fattah Eman M. (2017). Effect of boron, potassium and calcium on growth, yield and quality of two sugar beet varieties under sandy soil conditions. J. Prod., Mansoura Univ., 8(6): 699-704, 2017.

Besheit S.Y., Mekki B.B. and EL-Sayed M.A. (1995). Yield and technological characters of sugar beet as affected by rates and time of nitrogen application. J. Agric. Sci. Mansoura Univ., 20(1): 6169.

Brown J.D. and Lilliand O. (1964). Rapid determination of potassium and sodium in plant material and soil extracts by Flamphotometry. Proc. Amer. Soc. Hort. Sci., 48: 341-346.

Carruthers, A., Oldfield J.F.T. and Teague H.J. (1962). Assessment of beet quality. Paper Presented to the $15^{\text {th }}$ Annual Technical Conference, British Sugar Corporation LTD. 36 pp.

Cattell R.B. (1965). Factor analysis on introduction to essentials. The purpose and underlying models. Biometrics, 21: 190-215.

Crivineanu C. (1995). Studies on the influence of mineral fertilizers on sugar beet yields. Seria A., Agron. 38:81-86 (C.F. Field Crop absts., 50 (10) 1997).

El-Geddawy Dalia I.H. and Makhlouf B.S.I. (2015). Effect of hill spacing and nitrogen and boron fertilization levels on yield and quality attributes in sugar beet. Minufiya J. Agric. Res. 40 No. 4(1): 959-980.

Enan S.A.A.M., Aly E.F.A. and Badr A.I. (2016). Effect of humic acid and potassium on yield and quality of some sugar beet varieties in sandy soil. J. Plant Prod., Mansoura Univ., 7 (2):289- 297.

Enan S.A.A.M. (2011). Effect of transplanting and foliar application with potassium and boron on yield and quality of sugar beet sown under saline soil conditions. J. Biol. Chem. Environ. Sci., 6 (2): 525-546. 
Hills F.J. and Albert U. (1971). Nitrogen nutrition. P.112-135. In: R.T. Johnson, J.T. Alexander, G.E. Rush, and G.R. Hawkes (eds.) Advances in sugar beet production: principles and practices. The Iowa State Univ. Press, Ames, Iowa, USA.

Ghareeb Zeinab E., Ibrahim Hoda E. A. and Elsheikh S.R.E. (2013). Statistical and genetical evaluation of fifteen sugar beet genotypes under three sowing dates. Egypt. J. Plant Breed., 17(5) 69-81.

Hozayn M., Abd El-Monem A.A. and Bakery A.A. (2013). Screening of some exotic sugar beet cultivars grown under newly reclaimed sandy soil for yield and sugar quality traits. J. Appl. Sci. Res., 9 (3): 2213-2222.

Kaiser H. F. (1958). The varimax criterion for analytic notation in factor analysis. Psychometrica, 23: 187.

Kemp P.D., Khani A.M. and Millner J.P. (1994). The effect of plant population and nitrogen level on sugar yield and juice purity of sugar beet (Beta vulgaris, L.). Proc. Annual Conf. Agron. Soci. of New Zealand, 24: 131-134. (C.F. CAB Abst).

Mohamed S.A., Mohamed D.H.D., El-Sayed I.G. and Hamdy A.A. (2014). Impact of boron foliar application on quantity and quality traits of sugar beet (Beta vulgaris L.) in Egypt. RJPBCS, 5(5): pp. 143155.

Moustafa Zeinab R., Moustafa Shafika N., Beshay Maria G. and Abou Shady K.A.
(2000). Influence of nitrogen fertilizer on some quality, technological aspects, productivity and amino acids accumulation of sugar beet. J. Agric. Sci. Mansoura Univ., 25(8): 4795- 4806.

Omar A.E.A. and Mohamed H.Y. (2013). Effect of nitrogen and bio-fertilization on yield and quality of sugar beet under drip irrigation in newly reclaimed sandy soils. Zagazig J. Agric. Res., 40 (4): 661-674.

Piper C.S. (1955). Soil and plant analysis. Univ. of Adelaide, Australia, P.178

Reinefeld E.,, Emmerrich A., Baumgarten G., Winner C. and Beiss U. (1974). Zur varaussage des Malassezyu chers aus Robenanailysen. Zuker, 27: 2-25. The Sugar beet Crop. Cooke, D. A. and R. K. Scott. $1^{s t}$ ed. 1993. Chapman \& Hall (World Crop Series), London, UK.

Seiller G.J. and Stafford R.E. (1985). Factor analysis of components guar. Crop Sci., 25:905-908.

Snedecor G.W. and Cochran W.G. (1981). Statistical methods 6th Ed. Iowa State Univ. Press. Ames. Iowa, USA.

Steel R.G.D. and Torrie J.H. (1980). Principles and procedures of statistics. A Biometrical Approach, $2^{\text {nd }}$ Ed., Iowa State Univ. Press, Ames, Iowa, USA.

Stevens W.B., Alan D.B., James M.K., Bryan G.H. and Jason W.E. (2007). Sugar beet yield and nitrogen use efficiency with preplant rboadcast, banded, or pointinjected nitrogen application. Agron. J., 99:1252-1259. 


\section{إستجابة حاصل وجودة بعض أصناف بنجر السكر للتسميد بالنيتروجين والبورون فى الأراضى الرملية}

إسلام فتحى عبد الفتاح على - حدى محمد يوسف البقرى - نبيل إسحق جرجس ميخائيل

قسم بحوث الدحافظة على الأصنافــ معهُ بحوث الدحاصبل السكرية و *الهعدل الدركزي لبحوث التصديم

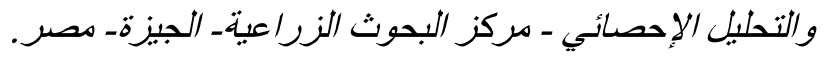

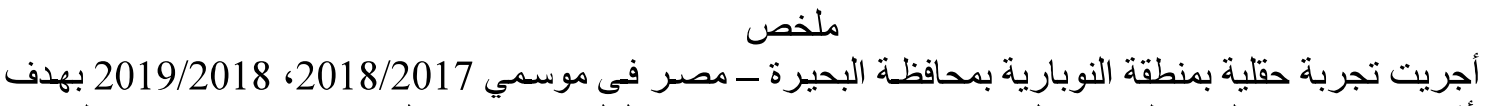

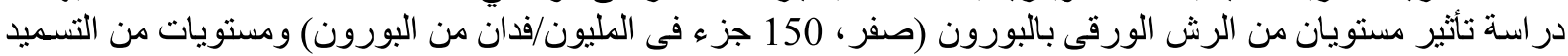

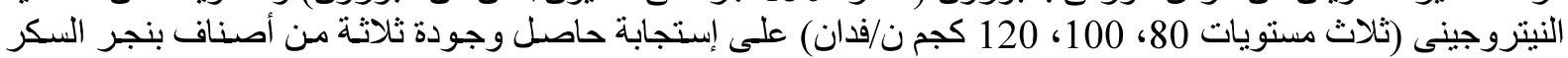

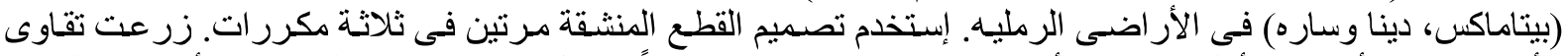

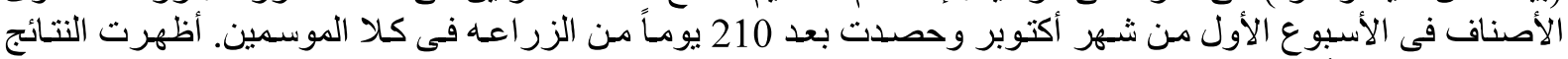

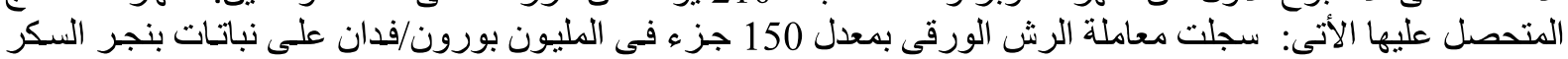

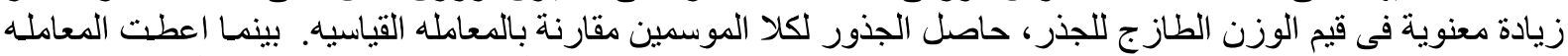

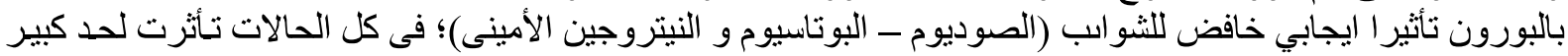

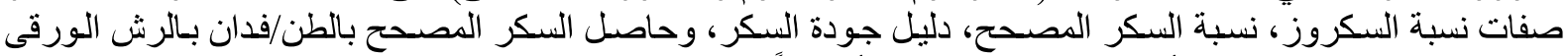

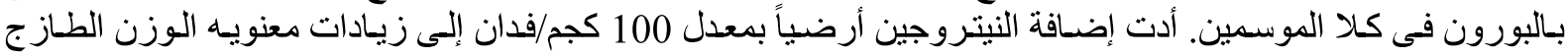

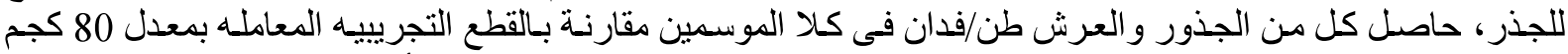

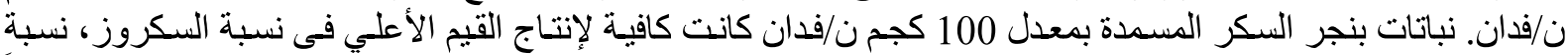

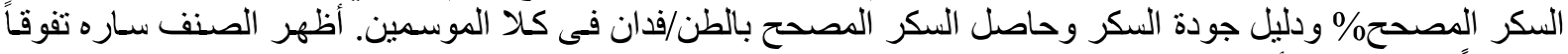

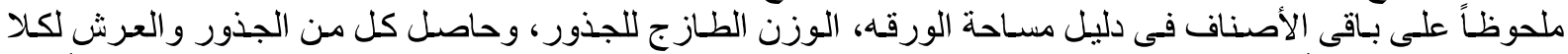

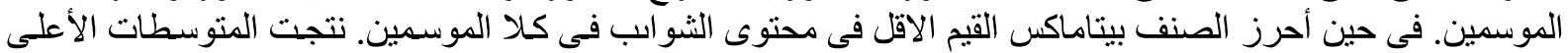

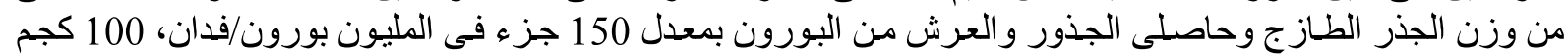

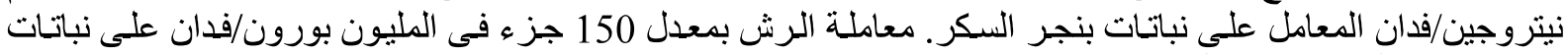

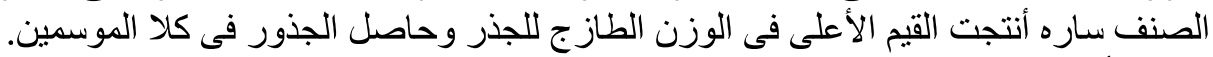

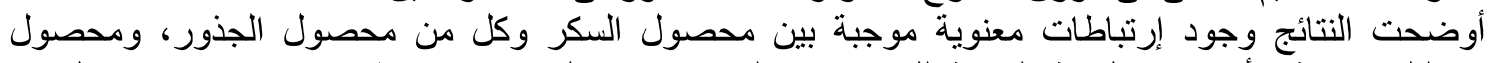

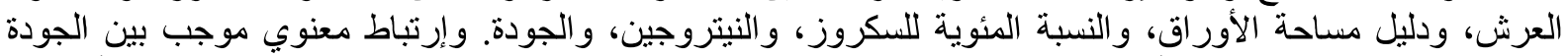

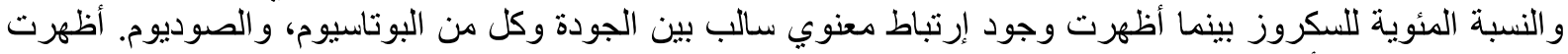

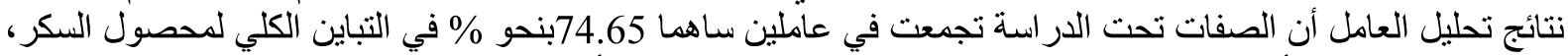

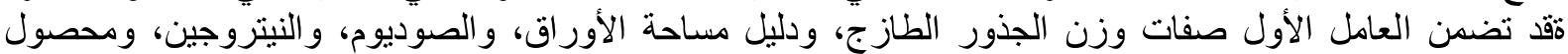

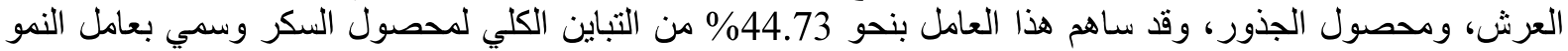

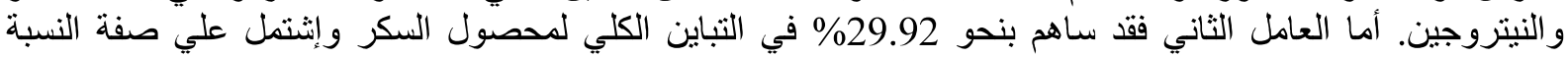

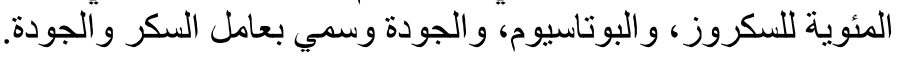

المجلة العلمية لكلية الزراعة - جامعة القاهرةـ المجلا (71) العدد الثانى ابريل (2020):105-95. 